\begin{abstract}
The main objective of this paper is to contribute to the discussions on the collective ecological food initiatives in Turkey that the academic literature has to a large extent ignored. This study provides a current and detailed analysis of these initiatives in Turkey, whose momentum has expanded considerably in recent years, especially in Istanbul. The study investigates food communities and consumer food cooperatives as two significant forms of consumer-led collective ecological food initiatives, comparing these in terms of their motivations, organization models, and functions. A comprehensive picture of almost 20 consumer-led ecological food initiatives is presented, and 11 prominent examples of these possessing transformative ambitions in Istanbul are discussed in detail. The fieldwork is based on my participant observation of the Kadıköy Cooperative, of which I have been a member for one year, and close interactions with the members of other ecological food initiatives for two years, as well as 20 in-depth interviews with the members of these initiatives. This paper examines the commonalities in these initiatives that differentiate them from other alternative food channels, as well as the connections, relationships, and collaborations among these recently emerging collective ecological initiatives. The paper discusses concrete examples of the alternative relations in food production, distribution, and consumption that these urban ecological food initiatives try to offer in practice and that indicate the potential power these initiatives have for transforming current food relations and for contributing to the emerging food sovereignty struggle in Turkey. The study also illustrates how the consumers and producers in this network of initiatives have conceptualized their practices and ambitions within the food sovereignty movement. Keywords: Consumer food cooperatives • Food communities • Collective and Ecological Alternative Food Initiatives • Food sovereignty • Small ecological farming
\end{abstract}

1 Correspondence to: İrem Soysal Al, Sociology Department, Graduate School of Social Sciences and Humanities, Koç University, ìstanbul Turkey. Email: ial15@ku.edu.tr ORCID: 0000-0001-5604-4756

To cite this article: Soysal Al, i. (2020). The promising momentum and collective practices of the recently expanding network of consumer-led ecological food initiatives in Turkey. İstanbul Üniversitesi Sosyoloji Dergisi, 40, 129-162. https://doi. org/10.26650/SJ.2020.40.1.0046 
To understand the recent emergence of collective ecological initiatives in Turkey, we need to first address the rise of the organic and post-organic movements in Turkey and abroad, as well as the dynamics of the corporate industrial food regime that endangers small-scale ecological farming, our health, and nature. Along with the modernization of agricultural production after World War II through the Green Revolution, technology and capital have gradually replaced labor since the 1950s, increased productivity, and reduced food prices. Nevertheless, conventional largescale industrial agriculture has also gradually brought severe ecological and social consequences. The dependence on fossil fuels and the extensive use of herbicides, pesticides, and fertilizers have resulted in significant environmental degradation and health problems. Agriculture in the northern hemisphere has witnessed a reduced number of small-scale farms with concentrations of larger and more capital-intensive production, especially since the 1970s. Protectionist policies have gradually declined and are incrementally being abandoned; neoliberal policies such as reduced import taxes and abolishing subsidies favor open markets. Especially after the foundation of the World Trade Organization (WTO) in 1995, small and medium-scale farmers were placed in competition with the agro-industries and have become increasingly dependent on world market prices. Consumers have largely lost their knowledge on how, when, by whom their food is grown and delivered. The organic agriculture thus arose as a movement in the USA in the 1970s, along with the influence of its radical political context (Goodman \& Goodman, 2007), as a reaction to the on-going rise of agricultural companies and industrial food. The conversion to organic farming has also been encouraged in European Union (EU) countries since the 1990s. Along with the food anxieties and the rising food consciousness, the demand for organic farming in Europe has accelerated, especially over the last two decades. According to a report from the European Commission (2011), over the last decade, the area of organic land in the EU increases by half a million hectares each year. Today, over 186,000 organic farms are found across the EU, as well as a considerable organic per-capita consumption in the EU-28 countries (47.4 Euros in 2014; Research Institute of Organic Culture [FIBL] \& the International Federation of Organic Agriculture Movements [IFOAM] EU, 2016).

Turkey's industrial production started to get a hold of agro-ecological family farming beginning in the 1950 s but has been out of control since the $1980 \mathrm{~s} .{ }^{1}$ Neoliberal agricultural policies have been adopted in Turkey, especially during the 2000s after the Agricultural Reform Implementation Project (ARIP) signed

1 The first radical diversion from protectionist policies was seen in 1980, with the enacted "January 24th Decisions" after the coup d'état in September 1980. The January 24th Decisions involved many aspects of structural adjustment programs from the World Bank and the stabilization policy package of IMF, such as devaluations, the removal of price increases in state economic enterprises, price controls, restrictions on support purchases, and customs exemptions for imported inputs (Günaydın, 2014, p. 519). 
by the pressures of the International Monetary Fund (IMF) and the World Bank. ${ }^{2}$ During the last two decades, state economic enterprises (SEEs) that make support purchases and provide input have been shut down and disbanded or been privatized, ${ }^{3}$ the same goes for the integrated processing factories of farmers' cooperative unions. Agricultural input has increasingly become more expensive; thus, farmers cannot get stable or fair prices for their products. The state also charges producers and consumers nearly the amount of the budget for its agricultural support, through many taxes such as value-added tax and special consumption tax are found in the final price of products (Günaydın, 2014). The reduction of publicly managed agriculture has thus left unorganized farmers on their own to confront powerful organized capital and have been incrementally more exploited as a result. A significant example indicating the changing dynamics of labor relations is the rise of contract farming between farmers and agro-food companies. In the most common form of contract-farming, the company that signs the contract proletarianizes farmers on their own land by determining which agricultural inputs will be used as well as the properties and prices of the standardized quality product they demand. The knowledge of farming also loses its importance under these conditions because the corporations, no longer the farmers, are the ones who decide the type of crop and seeds for production, the time of cultivation, and the numbers of fertilizers and pesticides to be used. Even worse, they are obliged to use the pesticides, synthetic fertilizers, and industrial seeds corporations impose, unless they practice organic production. Even in organic production, they have no option of using their own heirloom seeds, but mostly the hybrid organic seeds the corporations provide. These conditions have resulted in alienating farmers from their own production. Most farmers have already started to forget how to cultivate the land and protect their crops without using agricultural chemicals because they are used to the hybrid seeds of the global seed agro-businesses, which also require a high amount of synthetic fertilizers and chemicals. Many local heirloom seeds are also unknown by most farmers, let alone the consumers. Therefore, this period has led to small-scale

2 The Agricultural Reform Implementation Project (ARIP) aimed to gradually transform towards a free market where the state does not manipulate market conditions, prices, or volume of agricultural products with respect to changing government policies. The objective was for farmers to make their own decisions in production and sales by considering market conditions and finding loans from private banks. ARIP also required removing minimum pricing practices as well as grants for fertilizers, fuel, seeds, and agricultural credits; it left farmers to free-market dynamics (Keyder \& Yenal, 2013, pp. 198-201).

3 For instance, the Sugar Law No 4634 was enacted in April 2001 and aimed to remove the burden of the sector from the Treasury. After this law, two subsidiaries of the state-owned enterprise Türkşeker were privatized in 2004 and 2005 (EU Report, 2006). Similarly, the Tobacco Law 4733 was enacted in 2002 to eliminate state procurement of tobacco. Following this law, TEKEL (state monopoly of beverages and cigarettes) was divided into two groups, one for tobacco and the other for alcohol, and they were privatized separately. The alcohol part was sold to Mey Beverages in 2004, which sold $90 \%$ of its shares in 2006 to an American monopole, the Texas Pacific Group. Its tobacco part was also sold in 2008 to the British-American Tobacco Company (Aydın, 2010, p. 173). 
farming gradually disappearing and the previous agricultural structure of Turkey being abandoned where in small-scale farmers used to be supported by the state and had greater sovereignty within their production processes than today.

Along with these developments over the last two decades, food-related problems in Turkey have become more critical. The Food and Agriculture Organization of the United Nations (FAO, 1999) defines food safety as "an assurance that food will not cause harm to the consumer when it is prepared and/or eaten according to its intended use." In terms of food safety, the increasing use of pesticides has been dramatic in Turkey. For instance, according to data from the Ministry of Food, Agriculture, and Livestock, the use of glyphosate in Turkey, a chemical that disrupts the hormonal system, has multiplied by 15 times, reaching from 305 tons in 2001 to 4,500 tons in 2017 (Ş1k, 2017). The notions of food security, food safety, and food sovereignty in fact need to be elaborated upon in relation to each other because these approaches are complementary. Food sovereignty, ${ }^{4}$ being the more comprehensive notion, considers the perspectives that food security and food safety define and are concerned with; however, its approach is not just from the technical and legal perspectives. It thus also addresses the political grounds for how to struggle for and sustain the rights defined by these notions. For instance, it makes an issue of farmers' rights to have control over their agricultural practices, bringing to the table the political discussions, strategies, and ways to do so. It also makes issue of the as yet ignored ecological dimensions, such as respecting biodiversity and the ecosystem in the current agro-food production. Therefore, the main questions this study asks about the collective ecological food initiatives in Turkey appear as "How can people practically build sovereignty in their own agricultural and food practices, considering the particularities of their local conditions?" and "How can people struggle to revive small-scale ecological farming where small producers can get fair prices for their labor and consumers can eat healthy ecological food at reasonable prices?"

In Turkey where this industrial corporate agro-food context pressures producers and increases the risk environment for consumers, many farmers are also trying to shift their farming into organic or post-organic alternatives. Turkey initiated its organic agricultural policies within the framework of the process of harmonizing with the European Union in 2004 and has since then been carrying out certain support policies for organic agriculture. The state in particular supports the production of organic fruits and vegetables and local products that have a potential export value. Also, the extent of this support is correlated with producers' land size. Hence, the state support for most small-scale organic producers remains

4 La Via Campesina, the international organization of farmers, uses, for the first time, this notion publicly in 1996 as in the following declaration. See "A guide to Food Sovereignty", European Coordination Via Campesina, 2018. 
insufficient for covering certification expenses, especially because of the dramatic loss in value the Turkish Lira has suffered in five years relative to the payment currencies. ${ }^{5}$ Nevertheless, the land cultivated for organic farming has also increased from 162,193 hectares in 2004 to 278,726 in 2018 (Ministry of Agriculture \& Forestry, 2019), and organic agriculture's share of the total agricultural activities rose from $0.3 \%$ in 2002 to $2 \%$ in 2016 (Ministry of Food, Agriculture, \& Livestock, 2018). Transnational and national corporations, as well as many urban entrepreneurs and farmers, have also incrementally penetrated the organic market. However, the increase in implementing organic agriculture in Turkey has not been felt as a considerable increase in the per-capita consumption of organic food consumption in Turkey, which remained at 1 Euro in 2014 (FIBL \& IFOAM, 2019). Thus, these statistics help at understanding that a significant volume of the organic foods produced in Turkey are exported, with the rest being consumed by economically privileged consumers. In 2006, Buğday Ekolojik Yaşamı Destekleme Derneği [The Wheat Association for Supporting Ecological Living; WASEL] initiated its project for organic farmers' markets to both support certified organic food producers and provide certified organic foods at lower prices compared to those in organic stores. After its first market in İstanbul, the association also organized others in Kartal, Bakırköy, Beylikdüzü, İzmit, and Kocasinan and their relevant municipalities in the following years (WASEL, 2019). Only certified organic foods are sold in WASEL's organic farmers' markets, and intermediaries as well as the producers can sell food in these markets. Today, Turkey has more than 10 organic farmers' markets. In addition to WASEL's, Organik Yaşam Derneği (ORYAD [Association of Organic Living]) also organizes organic farmers' markets in Kemerburgaz, Göztepe, Maltepe, and Bodrum in collaboration with relevant municipalities, Slow Food organizes the Şile Earth Market, and Eskişehir Tepebaşı Municipality organizes the Tepebaşı Organic Farmers' Market (Ekoharita, 2019).

In the 2010s, organic foods started to become more popular in the public discourse and to be consumed more by the middle and upper classes. This period (especially after the Gezi Park protests in 2013) has also witnessed an increasing number of ecological actors in Turkey, such as ecological schools, urban gardens, ecological associations, and other awareness actors in the area of ecological living. Post-organic food actors emerged in Turkey in this very context in the last decade, growing side by side with the organic food actors. These initiatives have of course been influenced by the rise of post-organic initiatives (farmers' markets, cooperatives, and community-supported agriculture groups) in the world. Turkey's post-organic food market is already a complex market with various actors. A recent paper (Soysal Al \& Küçük, 2019) investigating the main actors in Turkey's organic

5 European Central Bank (2020) data indicate 1 Euro $\approx 7.7$ TL in June 2020, while 1 Euro $\approx 2.8$ TL in June 2014 (Accessed in June 2020). 
and post-organic markets categorized the Turkish post-organic movement as having two alternative forms. This categorization is helpful for distinguishing the collective and participative wing of the post-organic movement (consumer food cooperatives and communities/collectives) that have risen in Turkey from the so-called 'natural' food chain stores that offer village foods without certification, 'natural' food shopping sites of private farms, and other 'natural' food stores. The collective ecological food initiatives in the post-organic movement usually consider the organic movement as an alternative that no longer has any considerable transformative power because of how it has reproduced a monoculture focusing only on niche products and how it is dependent on the organic inputs of corporations while ignoring various other aspects in agricultural production and consumption such as the fairness of labor processes and accessibility of healthy foods (Buttel, 1997; Buck, Getz, \& Guthman, 1997; Goodman \& Goodman, 2007). Therefore, they try to offer new forms for producing and distributing ecological foods to empower small-scale farming and local food chains without requiring organic certification while respecting the ecology and using agro-ecological techniques. As opposed to the word 'organic,' which the organic movement uses to qualify certified organic products in the organic market, the post-organic actors usually describe their products as 'ecological' or 'natural.' Ecological as a word is preferred by consumer food cooperatives and communities in Turkey to highlight their holistic approach to ecology and their appreciation of the agro-ecological peasant techniques and knowledge in order not to reduce farming only to the use of certified organic inputs nor to the production of healthy foods with natural qualities.

Jones et al. (2010) put forth that, as a researcher or an actor in alternative food initiatives, we always need to focus on how these initiatives, with all their socioeconomic and ecological dimensions, are positioned against neoliberalism and to analyze whether they try to offer meaningful transformative alternatives that go beyond creating just another option in the market for consumers with a neoliberal logic. I appreciate this remark as an activist-researcher and thus focus this paper on the civicled collective and participative ecological food cooperatives and communities in Turkey that aim to build alternative agro-food relations in favor of small-scale producers, consumers, and ecology with the recent emergence of the food sovereignty approach 
in Turkey. ${ }^{6}$ The meaningful alternative food initiatives indicated here cannot be considered separate from the food sovereignty movement, as it fights for the rights of peoples to stand against the detrimental agro-food relations that conventional agriculture creates for small producers, consumers, human health, and the ecology. I define food sovereignty here by referring to the definition given by Abdullah Aysu (2015), the former president of the Farmers' Union in Turkey, as this definition, I argue, summarizes clearly the position of the initiatives studied in this paper, especially of the ecological food cooperatives. Food sovereignty is an umbrella term that defends a food system in which producers have control over their agricultural processes starting with seeding and ending with the marketing and transfer of food to consumers. It signifies production that respects biodiversity without harming nature or humans, and preserves the vocation of farmers using their local knowledge and techniques. The food sovereignty movement also defends the consumers' right to have easy access to ecological and local food.

The food sovereignty movement is both a reflexive response and an alternative political ontology that aims at building alternative values to the self-valorization of capital (McMichael, 2013, p. 156). It is also a response to the world-wide emergency in order to increase the rights and capacities of small producers who are pressured by state-supported corporate attacks on their farm economies (McMichael, 2016, p. 659). It is a global struggle to replace the sovereignty of agro-food corporations with the food sovereignty of the consumers and producers who care about healthy, ecological, fair, and accessible food. The farmers and consumers across the world have been increasingly making an issue of the global commoditization of food and farmers' loss of control over their land, as well as ecological degradation and expanding distance between the urban and rural through alternative initiatives and movements. Thus, investigating the position and practices of the emerging urban ecological food initiatives in Turkey, which have positioned themselves in the food sovereignty movement, has also become both a practical and an academic necessity.

6 I have not included some important actors, such as WASEL, in this discussion, despite their being significant actors for raising awareness and training about the dangers of conventional farming, the expansion of organic agriculture, and organization of organic farmers' markets, because I have focused this paper only on the more inclusive and collective ecological food initiatives based on public participation and citizens' self-organization. I regard WASEL's project as an example of a non-participatory alternative. WASEL acts as a significant actor in terms of ecological living and organic alimentation; however, it excluded consumers from the organization processes of organic farmers' markets for 12 years, which is unlike how food communities and cooperatives function. Consumers in these organic farmers' markets do not participate in decision-making processes, nor do they take responsibilities in the functioning of these initiatives. Nevertheless, WASEL should importantly be noted for having recently decided to transform its project of organic farmers' markets into a more citizen-led platform. It initiated a Communication Network of Prosumers and commissions where producers, consumers, the municipality, and NGOs act together as decision-makers and organizers of the organic farmers' markets. These developments have apparently been influenced by the rise of citizen-led food cooperatives and communities and may also transform the dynamics of organic farmers' market into being more participative and inclusive. This may also transform consumers' consideration of these markets (toward being more than another food channel) because they will also have the opportunity to engage actively in this project by embracing WASEL's political perspective that has led the activist stance with its criticisms against the current agro-food system. 


\section{Methodology and Research Design}

In this paper, I present a picture of nearly 20 consumer-led ecological food initiatives in Turkey, discussing 11 of them in detail while my analyses do not ignore the producers in their networks. I conducted 20 in-depth interviews with some producers and consumers from these initiatives: 10 interviews are with volunteers from the Kadıköy Cooperative, Beşiktaş Cooperative Initiative, Yeryüzü Food Communities, and Dürtük Food Collective, and 10 interviews are with producers from this network of initiatives in Istanbul. The volunteer members I interviewed are mostly graduate students and young employees in the private sector between the ages of 25 and 35. I have an almost equal number of female and male interviewees. I also draw from my year-long participant observation at the Kadıköy Cooperative as a volunteer member, in addition to elaborating on my constant interactions and discussions with volunteers from other initiatives from several meetings, workshops, and public events. I have also been following these initiatives' social media posts since the beginning of their formations. Therefore, my in-depth interviews and participant observation, combined with my close interactions with and observation of these initiatives, provide comprehensive data on these recently yet rapidly expanding collective ecological initiatives that have transformative ambitions in Istanbul but that have largely been ignored in the existing literature despite their increasing visibility.

By situating the emergence of the collective ecological food initiatives among the post-Gezi political context, the changing agro-food politics of Turkey, and the larger global context of agriculture and food politics, I try to respond to the following questions in this paper:

- What are concrete examples of the alternative relations these urban ecological food initiatives try to offer in practice for food production, distribution, and consumption that indicate the potential power of these initiatives for transforming existing food relations and that contribute to the emerging food sovereignty struggle in Turkey?

- What are the differences and similarities in terms of alternative visions, functions, and structures among these collective ecological food initiatives (i.e., food cooperatives and communities) that claim to offer alternative agro-food relations for consumers and small-scale ecological producers?

- How and with which motivations are collective ecological food initiatives established in Turkey? What is the agro-food context in which these civic ecological consumer food initiatives emerge? What impact has the Gezi Park protests and the post-Gezi political context had on the emergence of these initiatives, especially the democratic and participatory ecological food cooperatives where citizens act for themselves around a common and daily matter like food? 


\section{The Paper's Contribution}

This research aims to fill the significant gap in the literature on citizen-led collective ecological food initiatives in Turkey. Some of these cooperative initiatives in Istanbul have been presented once in Mekanda Adalet Derneği's [Center for Spatial Justice] journal Beyond Istanbul; some initiatives in Izmir have also been studied as part of a doctoral dissertation with a focus on their socio-technical practices as niche initiatives (Karakaya, 2016). Soysal Al and Küçük's (2019) comparative article is recently found on the various actors in the recent organic and post-organic market in Turkey, an ecological consumer food cooperative, a popular natural food store, and a well-known organic farmers' market in Turkey. Other than these, only some unpublished conference papers (Kocagöz \& Doğan, 2017; Kadirbeyoğlu, 2016) and a book chapter presenting some alternative food initiatives in Turkey (Kadirbeyoğlu \& Konya, 2017) can be found, but these do not provide a recent or detailed discussion on the specific collective ecological food initiatives that have multiplied in the last three years. However, this topic has been attracting increased attention, especially in Istanbul, Izmir, and Ankara in non-academic food-related workshops and panels. The topic is also addressed in almost every speech, interview, and online article from the managerial staff of the Farmers' Union [Çiftçiler Sendikası, formerly the Çiftçi Sendikaları Konfedarasyonu, Çiftçi-Sen], a crucial actor in agriculture on the part of producers. Therefore, the main objective of this paper is to provide a very recent and comprehensive picture of the alternative, civic, and cooperative food initiatives that have emerged with considerable pace and impact in recent years in Turkey, particularly in Istanbul.

As the interest in cooperatives and ecological/organic/natural products grows and the network of urban ecological food initiatives expands, I believe that the literature on these issues, which is currently very limited, will also become enriched in a few years. The publication of two very recent books on cooperatives in Turkey, Krize Karşı Kooperatifler: Deneyimler, Tartışmalar, Alternatifler [Cooperatives in the Face of Crisis: Experiments, Discussions, and Alternatives] (Öngel \& Y1ldırım, 2019) and Kooperatifler [Cooperatives] (Aysu, 2019), as well as the significant interest these books see at public events, are the signs of this literature's potential for growth. Aysu discusses the history of cooperatives, agricultural cooperatives, agricultural sales cooperatives and unions, agricultural credit cooperatives, and village development cooperatives in Turkey in his book. Krize Karşı Kooperatifler also addresses the traditional experiences of the producer cooperatives, corporate management of cooperatives, cooperatives throughout globalization and EU processes, and local governments' cooperative projects. That book also has an article written by the Kadıköy Cooperative where the cooperative presents itself as a new, consumer-led cooperative experience. However, the recently expanding network of various emerging collective food organizations is neither discussed nor elaborated on as major issues in these recent books. Given the considerable gap in this new field, investigating these new actors 
and discussing their promising momentum and collective practices appear very essential. This paper aims to serve this purpose and invite future researchers to study this dynamic field.

In brief, to positively contribute to this interesting, recent, and thus not much studied phenomenon in the sociology of food and agriculture, I not only present ecological food communities, collectives, and consumer cooperatives in Turkey in this paper, but I also compare them in terms of their main motivations, functions, and organizational forms. I also discuss the hope present both on the side of consumers/volunteers and producers in this network of collective ecological initiatives where citizens cultivate seeds together, as opposed to other post-organic non-participatory private initiatives that mostly have a mere health-oriented approach. To do so, I elaborate on how they conceive their current practices, plans, ambitions, and food politics. I also discuss their efforts to expand their impact in their struggle for food sovereignty, which is also an issue recently starting to be discussed in Turkey by activists in particular.

\section{Commonalities Among Turkey's Collective Ecological Food Initiatives That Adopt the Food Sovereignty Approach}

Heterogeneity exists among ecological food communities and consumer-led cooperatives. However, some of their common aspects differentiate them from many other natural and organic food alternatives. Most consumer-led ecological initiatives in Turkey are organized collectively by citizens in their locality to provide healthy food directly from small ecological farmers based on direct and trust-based relations both to access ecological food more easily and to support farmers who care about agro-ecology. Before elaborating on the civic ecological food initiatives in Istanbul, here I will list one by one the shared characteristics of the collective ecological food initiatives to provide a clear picture of their commonalities and discuss the differences between ecological food communities and cooperatives. The common features of collective ecological initiatives in Turkey also reveal their significance in the struggle of food sovereignty and what their actual and potential impact means in the larger agro-food context.

1) Growing solidarity relations with small-scale ecological farmers, through a locally organized collective effort in the city: Locale may mean the spatial organization of consumers on a neighborhood scale (e.g., Kadıköy Coop, Koşuyolu Coop) or on a university scale (e.g., BÜKOOP). Or consumers may work in collaboration with the producers of a particular local space (e.g., DÜRTÜK's project in Piyalepaşa Bostan). In the current food regime where "world agriculture" (food from nowhere) has been increasing consumers' anxieties and food risks, this search for a "place-based form of agro-ecology" (food from somewhere; McMichael, 2013, p. 156; 2009, p. 147) represents a common characteristic these alternative food initiatives have. When choosing these farmers, the scale here does not just indicate the size of their land. The 
limits on what defines small-scale land are a complex issue after all. The type and value of the products grown on this land and the agricultural land's location determine that land's and product's value. For instance, same-sized vegetable gardens, one near Istanbul and another in Niğde, cannot be compared just in terms of scale. Similarly, same-sized tea garden and orange garden do not bring the same financial income; thus, the size of the agricultural land is not the main determinant here. The most important criterion regarding producers is whether or not they have adopted corporate logic. These initiatives do not work with producers who adopt corporate logic, which reduces production into exchange value and focuses on profit-maximization. If producers are not producer cooperatives, they are usually family farms with only one or two employees outside of the family members if necessary. Given the increasing corporate sovereignty over food and agriculture, the considerable pressures of agro-food companies on small farmers, and the imposition of industrial agriculture, supporting the survival of smallscale ecological farmers who do not act with corporate motivations is vital and their importance needs to be emphasized more for the food sovereignty of peoples.

2) Building ecological relations: These initiatives do not work with any small farmer, just with those who use agro-ecological techniques and their local or heirloom seeds. These producers also do not utilize agricultural inputs like pesticides and herbicides, nor additives, food colorants, and food preservatives, all of which threaten public health. In so doing, they support environmentally friendly production and consumption relations for the benefit of society. In a context where conventional farming has incrementally been raising food anxiety and threatening biodiversity, where having access to healthy food is a luxury, efforts at building ecological and reliable food relations for all is essential for the food sovereignty struggle.

3) They aim at fostering direct and fair production and consumption relations based on ecological food producers' and consumers' collective actions: In this way, they target subverting the conventional distanced relations of urban consumers from production conditions. Neither consumers nor producers alone can transform the current agro-food relations. These direct and transparent relationships between consumers and producers, as well as their reciprocal responsibilities and initiative-taking, are vital in the struggle for food sovereignty. This is because as consumers are distanced from the agricultural production, they normalize limiting their own food 'choices' to what is on the supermarket shelves, consuming unhealthy food for high prices. Also, these direct sales channels are essential for supporting ecological farmers, most of whom are obliged today to sell their products to intermediaries for the same price as conventional products.

4) The food communities and cooperatives I address here do not require organic certification mainly because they do not want to aggravate their conditions with the extra bureaucratic and financial burden of getting a certificate: Trust becomes the 
main component of the relations between these initiatives and producers. Consumers in these initiatives mostly establish trust-based relations by increasing their interactions with the small farmers in their networks and visiting them when possible. They choose their producers, directly communicating with them about what they are looking for and what the producers' applications are, as well as by consulting the references of similar initiatives and producer unions.

5) Most of the collective ecological food initiatives in Istanbul are not affiliated with political parties but describe their efforts as political owing to their ambition to transform the current dominant form of production, distribution, and consumption of food: The majority defines themselves clearly as political actors in the struggle for food sovereignty, yet they prefer not having organics associated with political parties to remain more inclusive and participative. However, some such as Halk-Bes-Koop, Dayanışma Coop, and Ovacık Coop are organized by those with close ties to or affiliations with leftist organizations and parties like Halkevleri, the Communist Party of Turkey, and the Left Party (previously the Freedom and Solidarity Party). They also share the same ambition of supporting small-scale farmers who are under the pressure of corporations in the food and agricultural sector, expressing their political position clearly as against the capitalist industrial agro-food relations that are a detriment to small-scale farmers.

The fact that most of these collective ecological food initiatives share common fundamental principles and motivations also provides a good basis for collaborating together, opening up room for closer relationships and connections. As I will address and exemplify thoroughly in the paper, these initiatives participate in and collectively organize certain public events like panels and workshops to increase public attention and participation in these initiatives. They discuss strategies for acting together to build common logistics and storage. They try to plan some orders in common by preplanning the volume of products each of them expects to receive from their common producers and then consulting with their producers, sometimes organizing collective visits to these producers. As their number increases and these initiatives intensify their relations and collaborations, I argue that they will have more potential for providing alternative agro-food relations and will have a more effective joint role in impacting Turkish agricultural politics in the future.

We live in a political atmosphere where politics is conceived as an area where only political parties or the economic social organizations that are extensions of these parties can act because the state has "enclosed" the political sphere in a way similar to what Marx (2015) describes in Das Kapital (Capital) while referring to enclosure of the commons (Akçay \& Kocagöz, 2018, pp. 32-33). The state has managed to reduce politics into its own political field and has repressed all mass protests after the Gezi Park protests. 
However, organizations that have emerged with the Gezi spirit have not stopped the struggle. Citizens also try to have their voice heard in the food and agricultural politics, becoming part of these politics by acting through their local and participatory initiatives. Thus, Gezi constitutes a common historical background that has catalyzed the rise of these civic initiatives with claims of building horizontal and democratic organizational models. In particular, urban ecological food cooperatives like Kadıköy, Beşiktaş, and Koşuyolu coops relate their emergence directly to Gezi, as the intellectual foundations of these cooperatives formed in Gezi solidarity groups and forums.

In Figure 1, I have schematized the consumer-led ecological initiatives in Istanbul and the producer organizations in their network. I list here all ecological consumer food cooperatives and communities in Istanbul, as well as some producer organizations in their networks and the prominent actors in ecological living and food awareness. Consumers' collective ecological food initiatives such as Boğaziçi Mensupları Tüketim Kooperatifi ([BÜKOOP] Boğaziçi Members' Consumer Cooperative), Kadıköy Coop, and Beşiktaş Coop also are actors that raise awareness, especially regarding small-scale agro-ecological farming. In Figure 1, I thus illustrate the consumer-led food initiatives also as actors for expanding awareness on issues related to food and agriculture. The members of these initiatives are not engaged with farming. However, they are prosumers ${ }^{7}$ in direct contact with producers and have clear knowledge of the production conditions of the food they supply. Some collective consumer initiatives in particular regularly and reciprocally exchange knowledge with their producers, often visiting and helping them in their agricultural fields, planning together with the producers the volume of certain products to be bought before harvest, offering prepayment if possible when producers need, and thus trying to become part of both production and consumption relations. Therefore, I have positioned prosumers' cluster tangent to producers' cluster.

7 The word prosumer [türetici] is the combination of producer and consumer. This word is utilized in Turkey mostly to refer to consumers in collective ecological food initiatives who have direct collaboration with producers by mutually sharing the responsibility of production and consumption relations. 


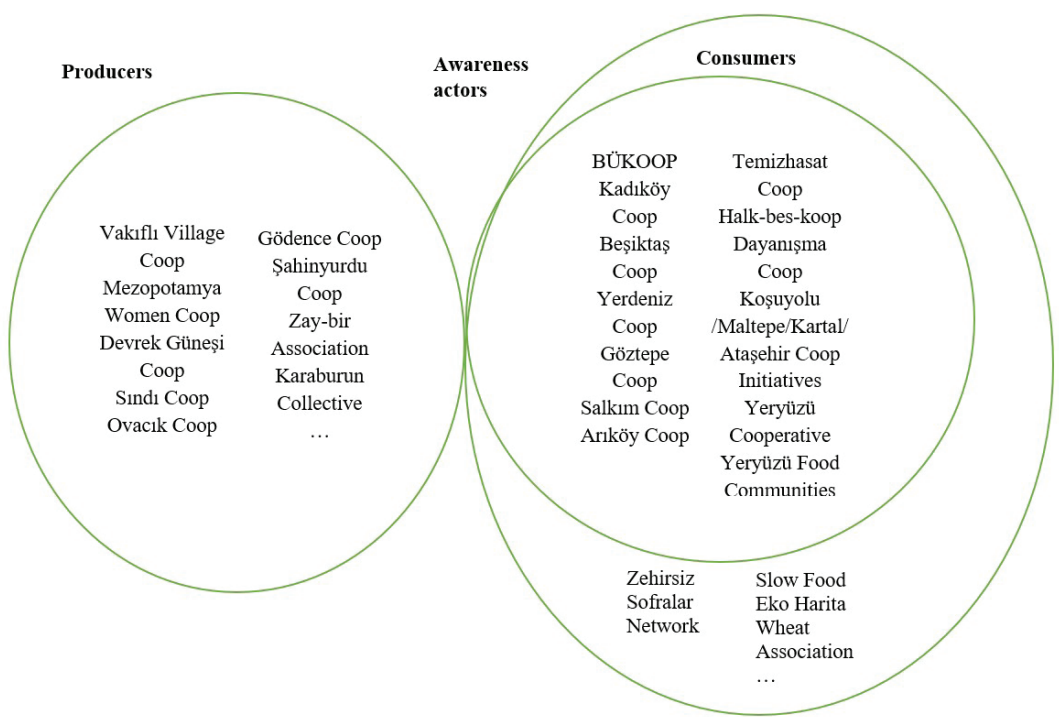

Figure 1. Awareness actors and consumer-led collective initiatives (food communities and consumer food cooperatives) in Istanbul and the producer organizations in their network.

\section{Civic Ecological Food Cooperatives in Istanbul}

Ecological consumer food cooperatives are freshly emerging actors in Turkey. The vast majority of these are organized by the inhabitants of Istanbul, citizens of the biggest and industrialized city of Turkey where consumers are positioned at a considerable distance from agricultural production. I thus present here the expeditiously enlarging network of recent yet more and more visible consumer-led ecological cooperatives in Istanbul, especially in the last three years, to draw attention to the momentum cooperative efforts around ecological food have gained in this environment where corporate sovereignty over agriculture and food stimulates risk. I present these cooperatives and discuss their common objectives to position them properly among the complex alternative food markets with their distinguishing characteristics from other so-called alternatives.

Bய̈KOOP: BÜKOOP was established in 2009 as the first consumer-led ecological collective food cooperative in Istanbul. The cooperative is located on the campus of Boğaziçi University and managed collectively by volunteer members consisting of students, academicians, administrative staff, and other personnel. The cooperative members are volunteers and do not gain money from their labor in the cooperative. 
Their objective is thus not income or profit, but mainly to provide healthy products at affordable prices while paying a fair price for the labor of small-scale ecological farmers and encouraging them to continue sustainable and ecological production. The university provides the cooperative with a free $40-\mathrm{m}^{2}$ store and all utilities such as electricity and computers. Considering the expenses other citizen cooperatives have such as rent, electricity, and maintenance fees, the fact that the university has unburdened such expenses is an important advantage. This is a crucial point because these expenses, in addition to transportation costs, are calculated and reflected onto the sustainability costs for other consumer cooperatives, thus increasing their prices. Unfortunately, the price increase creates a disadvantage in regard to economically challenged citizens' access to ecological products, despite these cooperatives placing no profit margin and only allotting money from the budget for cooperative expenses and sometimes a small fund for solidarity with disadvantaged groups. Like other cooperatives, the existence of BÜKOOP store also allows bulk orders and decreases producers' labor and transportation expenses, compared to producers who individually ship cargo.

The cooperative demands no organic certification from producers in order to not pressure them with the burden of certification costs and bureaucratic procedures. However, their producers engage in ecological farming, adopting local agro-ecological techniques and using local seeds in addition to environment considerations, biodiversity, and valuing local products in their region. BÜKOOP volunteers find their producers by consulting references from the Farmers' Union and other food cooperatives/ communities, as well as through their research and producers' practices. Their products range from legumes and rice to olives and mandarin oranges. They try to establish trust-based relations with producers who conform to these production criteria by directly contacting the producers. They also value the importance of visiting their producers and witnessing their production process, yet these visits are not very often because of a lack of time and money. The time shortage results mainly from the restricted number of active volunteers. In fact, as of 2018, the cooperative had almost 200 official members and 40 volunteers. However, the number of active volunteers is usually less than 10 people, mainly because of outgoing and graduating students and the intense course schedule current students have. Each volunteer is responsible for managing relations with one or more producer to arrange orders. Volunteers collectively manage receiving, storage, and sale of products as well as bookkeeping, payments, and store cleaning. When considering the lack of active volunteers and the most active visiting hours of the campus store, volunteers are seen to open their store only for an hour each weekday. The limited open hours, of course, restrict the number of consumers and, in turn, the volume of products they order from producers.

The cooperative welcomes the participation of citizens from outside the campus; however, it remains closed to consumers from outside the university because the 
cooperative store is on campus. Therefore, it is publicly visible and easily accessible only to the Boğaziçi students and staff, restricting its reach to a wider range of consumers and narrowing its participative structure. Nevertheless, the cooperative's contribution to supporting small-scale ecological farming and its efforts toward affordably healthy food for consumers is significant, especially because it is a pioneering example for the similar cooperatives that emerged in the following years, in particular the Kadıköy Coop that opened the first neighborhood-scale ecological consumer food cooperative in Istanbul. Their efforts to make consumers familiar with the producers and the production conditions of the food they eat are quite valuable in a context where consumers, especially young people, do not know how and through which production processes foods can be ecologically grown that conform to the natural rhythm of the seasons. Their collective work on the campus is particularly also considerably important because it also invites every person on the campus to this experience of collectivity around a common theme like food to participate equally in the discussions, decision mechanisms, and division of labor by challenging the hierarchies among academics, students, and personnel. This is an exemplary organization model on a campus that motivates young people to become agents with their own voice in an agro-food context that severely threatens their future and health and to communize the politics of foods as citizens through horizontal, participative, and democratic relations.

Kadık̈̈y Cooperative: The idea of establishing a food cooperative in Kadıköy emerged during the discussions in the forums and solidarity groups formed after the Gezi Park protests in 2013. In early 2014, with participation and guidance from BÜKOOP, Çiftçi-Sen, Anadolu'da Yaşam Coop, and Tohum İzi Association, the participants in these forums discussed the possibility of an ecological food cooperative in Kadıköy and a possible organization model for such a consumer-led cooperative. In 2015, a group of citizens in Kadıöy started the collective work, prepared a draft of the cooperative's organization model, and determined the main principles of the Kadıköy Cooperative Initiative. Before formally establishing the cooperative and opening its store in Kadıköy, volunteers practiced the dynamics of such cooperation and witnessed support for this food cooperative from the Kadiköy residents by organizing sales of food boxes (pre-ordered number of food boxes containing a few products) five times during 2015 and 2016. Since November 2016, Kadıköy Cooperative has continued its collective work around ecological food as a citizen-led collective and participatory initiative, possessing principles similar to BÜKOOP's. BÜKOOP and Çiftçi-Sen made great contributions to forming the ecological producer database for the Kadıköy Cooperative in its early phase. Kadıköy Cooperative later collectively developed its organization model as they learned and grew in experience. Like in BÜKOOP's case, volunteers do not earn money from their collective efforts, which aim to transform the current agro-food relations to the benefit of consumers, producers, and the environment. They organize producer visits, receive cargo, and open the 
cooperative store in turns, thus working collectively as volunteers to build ecological and horizontal social relations starting from locally.

Cooperative volunteers object to any kind of hierarchal relations in the cooperative and do not want any volunteer to be overly specialized in one area in the division of labor in their collective work to avoid possible unbalances in the equal and flat relations they try to establish. Thus, the volunteers cooperate in various working units through regular rotations, and the responsibilities each unit has collectively been defined according to the changing dynamics of their operations and strategies. These units are responsible for: continuous co-learning about the current agro-food system and agricultural policies in Turkey (Education Unit); managing relations and orders with producers and searching for new products (Product-Producer Relations Unit); handling book-keeping, payments, price setting, and cash audits (Financial Unit); managing all communication activities on social media (Communications Unit); organizing activities to increase the cooperative's recognition and participation from other citizens at this and other cooperative initiatives (Organization Unit). Different from BÜKOOP and many other cooperatives, volunteers also get together very often to discuss their collectively pre-determined weekly agenda and make decisions on that week's topics. Decisions in the cooperative are implemented by relevant working units and/or additional working groups. Decisions are made by consensus among the volunteers' ideas. This means that a decision is not made when one cooperative volunteer presents an objection for any reason. Hence, the cooperative volunteers do not ignore any single idea a volunteer working in this cooperative may have and, if needed, they postpone decisions for further discussions. This sometimes slows down operations, yet volunteers value this collective decision-making process as a good local experimentation of participatory democracy in Turkey, where the understanding of citizenship and democracy has been limited to elections. The cooperative also believes in the importance of efficiently transmitting and sharing knowledge among members and thus organizes constant learning workshops, with each working unit organizing regular meetings. Through these work mechanisms and participatory organization principles, the Kadiköy Cooperative has implemented a 'new generation' cooperative model in Turkey, as the volunteers also assert.

One of the main principles of the cooperative is to work with small-scale ecological farmers based on their mutual initiative and to collaborate to transform current production and consumption relations. Along with this principle, the cooperative works only with producers who use local and/or heirloom seeds in their production and who use no pesticides, herbicides, or synthetic fertilizers. The cooperative does not demand organic certification from its producers because of the same economic and political concerns BÜKOOP addressed above. It also pays attention to the production processes and continues their collaboration only with producers who do not exploit labor or 
employ children. Like other cooperatives, the Kadıköy Cooperative prioritizes working with women producers and female producer cooperatives. It also pays the utmost attention to making the payments to the women in the family to make sure that women are able to get compensation for their labor in farming. The cooperative embraces building social solidarity as a crucial principle and supports many disadvantaged communities, such as Migrant Women, Kazova workers, and Kadın Kadına Mülteci Mutfağ [The Women-to-Women Refugee Kitchen], by selling their prepaid products on their solidarity shelf that is separate from the ecological food shelves. The volunteers sometimes share food boxes with unfairly dismissed workers to show their support by using the relatively small amount of money in their solidarity fund. These practices reflect the cooperative's holistic understanding of solidarity, as well as the importance its volunteers give to the labor processes and women's economic empowerment.

Since the beginning of the Kadiköy Cooperative, its volunteers have spent considerable effort at expanding similar food cooperatives and objectively sharing their cooperative experiences - their faults, inadequacies, and what they have learned, as well as their motivations, dreams, and plans for collaborations with similar initiatives - to inspire and guide other groups in different locales to form their own collective and participative food cooperatives that are compatible with the dynamics of their neighborhoods. The Organization Unit is responsible for responding to meeting the demands and inquiries from groups who plan to form a consumer food cooperative. It also organizes monthly presentation days where volunteers introduce the Kadıköy Cooperative in detail and invite citizens to become volunteers in this cooperative work. This organizational logic makes Kadıköy Coop a more participatory public place than many other alternatives. A coop volunteer describes how Kadıköy Coop is distinct from other so-called alternatives that position themselves as 'alternative' to conventional food as follows:

We do not act with company logic. We try to construct a collective model as a civic initiative. We know that the society we live in adopts a neoliberal mentality, yet we try to reconstruct the public space. Think about Tazedirekt, for example. It is a platform that positions itself as an alternative venue for natural quality food. Does it have the same motivation as us? No. These actors act with the logic of profit-making and capitalist accumulation, and certainly, citizens cannot be agents in this system but only consumers trying to buy healthy food at the market. So what we do is much more comprehensive and beyond ensuring food safety. We try to create a public space where consumers have their say on what kind of agro-food model and farmers they would like to support and what kind of democratic participatory relations to construct with their collective practices, as well as to offer a real alternative to the existing agricultural system and current understanding of citizenship.

After establishing the Kadıöy Cooperative, the first neighborhood-scale ecological consumer food cooperative in Istanbul, citizens established 13 more consumer food cooperatives and initiatives, one after another, over the next three years (January 
2017-January 2020) with more or less similar motivations and principles. Former Kadıköy Coop volunteers also initiated two consumer cooperatives (Göztepe Coop \& Yerdeniz Coop in Yeldeğirmeni) in April and December 2019, and very recently a cooperative initiative in Maltepe, using the same motivations and work model and already having a similar cultural (all theoretical knowledge on Turkish agro-food system and food sovereignty movement) and social capital (a similar network of producers and consumers) from a Bourdieusian (1984) perspective. In forming these recent food cooperatives, the confident role provided by the successful efforts of the Kadıköy Cooperative is important. The increasing popularity and support Kadıköy residents show to the Kadıköy Cooperative and the intense efforts Kadıköy Cooperative makes to inform, guide, and motivate other groups are also crucial factors. Expanding such consumer cooperative initiatives and the efforts for a collective and participatory food politics is hopeful because these cooperatives have already started to cooperate. Beşiktaş, Koşuyolu, and Kadıköy Cooperatives have organized collective workshops on several occasions (e.g., the workshops at the Karaburun Scientific Congress) on the possibilities and limits of cooperatives and solidarity economies. They usually attend ecology festivals and panels together to discuss consumer cooperatives. In addition, they sometimes make collective orders from common producers to facilitate food transportation and reduce transportation costs. Despite the irregularity, the volunteers also visit their common producers together with other cooperatives, like in the case of their visit to Devrek Güneşi Cooperative in 2018. They also usually predetermine and inform their common producers at sowing and planting time about the volume of their orders for that year to help producers preplan production. A few cases exist where they found a producer from whom they had requested to start cultivating for these cooperatives using heirloom seeds according to their collectively defined criteria. A volunteer in Kadıköy Cooperative tells how they are motivated by the potential transformations they can trigger by collaborating with other cooperatives, detailing the following example:

We had difficulties finding an ecological lentil producer that year. There was a farmer that Abdullah Aysu (Çiftçi-Sen president) knows and trusts. But he was cultivating lentils using conventional methods. We convinced him to produce with the heirloom seeds that Abdullah Aysu had provided us with. We made a prepayment to this farmer to motivate him to cultivate lentils with these seeds using ecological methods for the $500 \mathrm{~kg}$ lentils we co-ordered with BÜKOOP. This is an example of how we can motivate farmers to engage in ecological farming (...) In the following years, we may tell the producer 'we, as seven consumer cooperatives, want to buy ecological lentils from you and you may not need to produce for the industry'. Or we may aim to transform the whole village in this way, as our impact grows together with an expanding network of organized consumers.

Almost a year after this interview, 13 initiatives (Beşiktaş, Kadıköy, Koşuyolu, BÜKOOP, Maltepe, Üsküdar, Ataşehir, Halkbeskoop, Anadolu'da Yaşam, and Salkım Cooperatives, Coop Initiatives, Kadıköy and Permakamp Food Communities, and 
Yeryüzü Association) organized a collective order of 1.5 tons of lentils from two small-scale ecological farmers in a Kars village. The collective order from only two cooperatives was already a promising solidary example one or two years ago in terms of cultivating the seeds of hope of growing solidarity among cooperatives. Today, we witness stronger steps toward growing the solidarity that the interviewee above expressed as a strong desire; this is more valuable than the volume of the collective order can reveal. It is also important that the sale of even 1.5 tons of lentils means a lot for a small farmer, considering the fair price they get without intermediaries. In addition, this means lower lentil prices for consumers as the bulk order decreases transportation costs. The expansion of similar ecological food cooperatives will also increase the collaboration among these cooperatives for co-planning and co-managing their orders through common logistics and common storage facilities. These common plans are now being discussed together as strategies for decreasing product prices by reducing transportation costs and increasing the support to producers by procuring a higher volume of products.

\section{Koşuyolu and Beşiktaş Cooperative Initiatives [Koşuyolu \& Beşiktaş Kooperatif} Girişimleri]: The residents of Koşuyolu, Acıbadem, Altunizade, and Barbaros neighborhoods founded the Koşuyolu Cooperative Initiative in January 2017. Similarly, a group of 15 citizens from Beşiktaş started their consumer food initiative in July 2017. These groups started their collective work sharing the same motivations as BÜKOOP and Kadıköy Cooperative. Their main objectives are thus to intimately know the producers and production conditions of the foods they eat and to support small-scale producers who cultivate healthy, safe, and ecological food without labor exploitation. They also procure their food directly and collectively from producers for fair prices. From the first day of their initiative, the volunteers from these cooperatives defined collective ambition and efforts as part of the struggle for food sovereignty, following the growing public discourse of the Kadıköy Cooperative and the Farmers' Union on food sovereignty in these years. These initiatives have had strong relations with Kadıköy Coop and BÜKOOP from the beginning. For instance, the first event Koşuyolu Coop organized was a forum with these cooperatives right after its foundation, where these cooperatives shared their own experiences with this new cooperative initiative. Kadıköy Cooperative also shared its producer database with Koşuyolu and Beşiktaş Cooperative Initiatives to help them to rapidly start their cooperative activities. In 2017, Beşiktaş and Koşuyolu Coop Initiatives declared their final objective as to establish an ecological consumer food cooperative; meanwhile, they continue their cooperation today in the form of a food community in terms of food distribution.

The political acquaintance among the group of neighbors in Koşuyolu started in forums after the Gezi Park protests, and consolidated through their solidarity in the Validebağ protests against the destruction of the grove in the neighborhood. This later 
created synergy to open further discussions and collaborations around food, which led to the Koşuyolu Coop Initiative being established. Indeed, the roots of most food initiatives can be related to the Gezi Park protests and the post-Gezi solidarities. Most of these groups thus share similar social and political sensibilities. They show their reactions to many problematic issues in Turkey, mostly on but not limited to ecological destructions, food-related hazards, and unfairly dismissed workers. In particular, the Koşuyolu and Beşiktaş Coop Initiatives and Kadıköy Coop have acted collaboratively on such things. For instance, they stood together in a coop cortege for the first time on Labor Day on May 1,2019. They also visited unfairly dismissed Flormar workers in protests and shared small food boxes with them as a gesture of solidarity. They went together to Bülent Şık's trial, who had been sued for publicly sharing the results of his scientific works about the relationship of industrial wastes with food hazards and the increased cancer rates in the Ergene Basin. Similarly, these cooperatives shared many reactive posts on social media about the mining project in the Ida Mountains and their collective participation in the climate strike in Istanbul. They publicly relate all these issues and events to their struggle for food sovereignty, addressing the fact that sustainable healthy food production directly relates to our respect for the ecology and sustainability of the whole ecosystem.

The volunteers from Koşuyolu Coop Initiative have organized several workshops (e.g., ecological bread making and pickling workshops) and panels (e.g., Food Security Panel with Bülent Şık and the 'No Patent for Seeds' Panel with other cooperatives) since the beginning of its formation in their community house provided by the Kadıköy Municipality. They have also organized events for children (e.g., exchange of books and toys) and documentation screenings about food and ecology (e.g., Food Coop, Seed: The Untold Story, and The Yurca Protests). The existence of this community center enables volunteers to invite their neighbors to such events and increase interactions and support for this consumer food initiative. They also gather once a month with other consumers in this community center for distributing food. Volunteers organized their first sales day a few months after their foundation in April 2017 and the second in the following October, respectively selling 50 and 100 food boxes. Similar to other ecological consumer food cooperatives in Istanbul, they also do not gain money from these sales, because they aim not at profit-making but at expanding such cooperation for food sovereignty. Volunteers prepare these food boxes (e.g., a small box of tea, beans, honey, and hazelnuts) by considering the e-mail orders from consumers who get together on a predetermined distribution day. Koşuyolu Coop Initiative organized its first biggest distribution event in September 2018, selling 250 $\mathrm{kg}$ of chickpeas from Ovacik Coop and $50 \mathrm{~kg}$ of sun-dried apricots that day. The volunteers have been organizing these monthly sales for a while. Koşuyolu Coop Initiative discussed in their second-year celebration events their projections and options for continuing as a formal food cooperative with a store or as a cooperative initiative; 
they decided to continue as a cooperative initiative for a while. Despite acting as a food community in terms of procuring and selling food, this cooperative initiative is now publicly more active than many food communities in Turkey in terms of acting with cooperatives and organizing food-related events. The volunteers from the Beşiktaş Coop Initiative, who started their collective work in the same year as the Koşuyolu Coop Initiative, have meanwhile decided to establish a formal consumer food cooperative with a store in early 2020 .

The Beşiktaş Coop Initiative started their cooperation in July 2017. It has similar motivations and principles as well as many common producers with the Kadıköy Coop and Koşuyolu Coop Initiative. Being in close interaction with the Kadıköy Coop volunteers, they also follow a very similar work model. For instance, they also meet weekly to collectively discuss their routine tasks and decide on plans. They work in distinct job commissions in dividing labor, such as the Products/Producers Commission and the Communications Commission, and their responsibilities are collectively predetermined. Like the Kadıköy Cooperative, they also organize events to present the cooperative initiative and increase support and volunteer participation in the neighborhood. Some Kadıköy Coop volunteers have also started working in the Beşiktaş Coop Initiative, as they live in this neighborhood and their organization model and principles are quite similar. Here, noting that most consumer food cooperatives in Istanbul usually guide some of their consumers to shop from other cooperatives in their neighborhood and start a new consumer cooperative in their locality, if none exists, to catalyze local cooperation around ecological food is important.

Beşiktaş Coop Initiative started its food sales in January 2018 with the motto "Fair ecological food has arrived in your neighborhood." The volunteers first organized events for the distribution of summer and winter food boxes upon pre-orders collected using Google forms. They later started organizing monthly distribution days, collecting online orders for nearly 20 different products. In late 2019, almost 60 households were buying from Beşiktaş Coop Initiative. Thus, having the support of their neighbors and feeling ready to become a legal consumer cooperative, volunteers started their search for a cooperative store and the bureaucratic procedures for open their store at the beginning of 2020. Having this cooperative store in Beşiktaş means having a permanent place to store and sell products and thus be able to give more voluminous orders with fewer transportation expenses. This means supporting a greater number of small-scale ecological producers and giving more support to their existing producers. With a cooperative store, the cooperative becomes more visible to a greater number of consumers, which would also increase the number of volunteers engaged in this cooperation as well as awareness for expanding such collective and participatory cooperatives. The volunteers from Beşiktaş Cooperative also believe in the solidarity they try to build with producers around fair ecological relations. One volunteer from 
Beşiktaş Cooperative, a university student who is also one of its producers in Izmir in the summer, depicts how these cooperatives can motivate producers to engage in ecological farming in rural spaces as their network grows:

Once I start spending the whole year in Karaburun, I plan to offer some other products in addition to olives, like tomato sauce, for example. I know that the cooperatives will buy these products if I grow them ecologically and prepare these sauces without additives. This surely motivates me to keep producing because I don't need to be concerned with finding market channels or contacting an intermediary. The existence of these cooperatives motivates me to live permanently in my village because I know that they will pay fair prices. The expansion of such initiatives can motivate other people to go back to their land and start farming.

\section{Dayanışma Cooperative, Halk-Bes-Koop, Temizhasat Cooperative, \& Ovacık}

Cooperative: Consumer-led ecological food cooperatives established by the collective efforts of the citizens affiliated with leftist political parties such as ÖDP, CHP, and TKP, and political organizations like Halkevleri (Community Centres) also exist. Their foundations also line up with the times other ecological cooperatives like Koşuyolu and Beşiktaş Cooperatives started. Dayanışma (Solidarity) Coop, Halk Iç̧in Doğal Gıda ve Sağlıklı Beslenme Tüketim Kooperatifi (Halk-bes-koop [Consumer Food Cooperative of People's Natural Food and Healthy Nutrition]), and Temizhasat [Clean Harvest] Coop consecutively started their collective businesses between November 2017 and January 2018. Dayanışma Coop has two cooperative stores in Beşiktaş and Kozyatağ1. Halk-Bes-Koop sells its products in the Halkevleri Taksim branch in Istanbul, and Temizhasat sells at its cooperative store in Şişli. Ovacık Consumer Cooperative also has three stores in Göztepe, Şişli, and Sultangazi neighborhoods. These cooperatives share similar motivations for supporting small-scale farming that respects ecology and human health. They also aim not at profit-making but at supporting small farmers and ecological farming in the context where these farmers have been rendered vulnerable in the capitalist and industrial agro-food relations. They state favoring small-scale farmers, ecology, local seeds; more comprehensively favoring peoples' food sovereignty over capitalist profit maximization, corporate food sovereignty, and industrial agriculture. They also aim at making healthy food accessible to a larger population, including lower classes, underlining that food is a social matter. They thus try to offer reliable ecological food for cheaper yet fair prices without any intermediaries though their collective organization united against food monopolies. Dayanışma Coop, Halk-Bes-Koop, and Temizhasat mostly sell products from farmers engaged in small-scale family farming. They mostly form their producer list through their political networks. Ovacık Consumer Cooperative, on the other hand, sells products from the Ovacik Producer Cooperative as well as products from many small producers and producer cooperatives in common with Kadıköy, Koşuyolu, and Beşiktaş Cooperatives. Ovacık consumer cooperatives are the most popular among them, with Ovacik Municipality giving growing support to local projects; this has led to the 
formation of Ovacik producer cooperative and later to many consumer food cooperatives in Ankara, İzmir, Adana, Mersin, Antalya, Bursa, and Eskişehir. These cooperatives also sell their products online, sending the orders by cargo, unlike Koşuyolu, Kadıköy, Yerdeniz, and Beşiktaş Cooperatives that consider cargo deliveries as an obstacle for developing face-to-face and close relationship with consumers, who are also potential participants in these and other collective works alike. This is, of course, a choice between selling larger volume products to provide more financial support to smallscale producers and realizing and expanding democratic participatory collective organizations while supporting small ecological producers.

These cooperatives also invite other citizens outside their already existing political network to participate in their organization. However, they rarely organize public presentation events for getting more volunteers in the cooperation. Also, they do not organize regular meetings that are open to the public. In that sense, they are not as participatory as the other citizen-led consumer food cooperatives that have no political party affiliation. Thus, although they offer a political alternative to existing agro-food relations, they ignore the other alternative pillar upon which cooperatives such as Kadıköy Coop for example position themselves: an alternative organizational model that prioritizes constructing horizontal relations in civic organizations and expanding citizen participation in the public space to impinge upon food politics. To make this argument clearer, one volunteer from Kadıköy Cooperative has explained this alternative pillar they try to build as follows:

The ground we stand on is not a closed-gated community; we invite people to a public space without boundaries to challenge the existing sovereign relations. To build food sovereignty, we need to challenge their 'sovereignty'; the sovereignty of the state, the sovereignty of corporations in the agro-food system... and of all kinds of hierarchal relations that silence citizens' voices in the public space, even in the new space we try to open through these civic organizations. Our efforts to build democratic, participative and horizontal relations in this cooperative business are directly related to these ideals we try to reach as part of our struggle for food sovereignty.

Recent consumer-led ecological cooperatives are also found (Kozyatağ1 Salkım Coop, Göztepe Coop, Yeryüzü Coop), and cooperative initiatives (Ataşehir, Maltepe, and Kartal cooperative initiatives) have emerged just a few months ago. Others like Şişli and Üsküdar cooperative initiatives either stopped their collective work or continue mostly as a closed group with no presence in public spaces. Arıköy Cooperative in Sarıer is also an example of a cooperative business with similar motivations but that is mostly disconnected from the other initiatives in particular because of its distant location from them. Founded in September 2018, Arıöy Coop has been carrying on its cooperation with small-scale ecological farmers without intermediaries, benefiting from the advantage it has of being closer to rural areas; it organizes workshops with producers, if not with other consumer cooperatives. When analyzed closely, the momentum citizen-led ecological cooperatives 
have created in recent years around ecological food is hard to ignore. However, food communities, hand in hand with consumer cooperatives, also have a crucial role in creating this momentum. Thus, I would like to elaborate now on the food communities in Turkey, focusing on those in Istanbul.

\section{Consumer-Led Ecological Food Communities in Istanbul}

Several consumer-led ecological food communities are found in the big cities of Turkey, such as Çanakkale Ekolojik Yaşam Inisiyatifi (ÇAYEK [Çanakkale Ecological Living Initiative]) in Çanakkale; Doğal Bilinçli Beslenme A $\breve{g} l$ (DBB [Natural and Conscious Nutrition Network]) and 100. Yll Glda Topluluğu [Centenary Foods Community] in Ankara; Homeros Food Community, Batı İzmir Topluluk Destekli Tarım Grubu (BITOT [West İzmir Community Supported Agricultural Group]), and Gediz Ekoloji Inisiyatifi [Gediz Ecological Initiative] in Izmir; Antalya Food Community in Antalya; and Bandura and Kuzey Adana [North Adana] Food Communities in Adana, in addition to those in Istanbul with larger networks.

Here I would like to investigate the food communities in Istanbul, as these initiatives have emerged predominantly in Istanbul, the largest and most industrial city of Turkey. I present DÜRTÜK, Köstebek Collective, and the Yeryüzü food communities in Istanbul, mostly focusing on the latter because Yeryüzü food communities are the primary and best-known expanded example of food communities in Turkey.

\section{Direnen Üretici-Tüketici Kolektifi (DÜRTÜK [The Collective of Producers and} Consumers in Resistance]): This is a collective food initiative in Istanbul, organized with the collaboration of both urban consumers and producers. The collective provides vegetables directly from the small farmers of Istanbul's historical vegetable gardens of Piyalepaşa and Yedikule Bostans, as well as some other small farmers around Istanbul. The collective emerged in 2015 with the motivation to defend the cultural heritage of these bostans [vegetable gardens] and urban food production. The volunteers collect orders using an Excel spreadsheet through e-mail and handle the logistics by receiving the orders directly from the producers' hands. The volunteers deliver them to consumers in the collaborative collective Dünyada Mekan, a place where unemployed and freelance workers are found. They do make profits from these sales. Their aim is to attempt to practically and legally sustain Istanbul's last bostans, whose existences are severely threatened by massive urban projects. DÜRTÜK volunteers additionally consider having sincere and direct relations with the farmers of these historical gardens important for building solidarity in an alternative economy, as one volunteer stated as follows:

What we do here can be considered an alternative economy of food consumption without intermediaries and distribution without pursuing commercial profit. The producers are who determine prices. This is certainly an alternative space... The volunteers take delivery of the products from the producers. This creates face-to-face and sincere relations with the producers. 
For example, we recently visited one of our producers in the Piyalepaşa bostan after he was taken to the hospital. Such initiatives will invite people to subvert the cold producer-consumer relations of today as well as to sabotage the superficial relations in modern industrial society.

An elderly family in Piyalepaşa Bostan needed animal manure but could not afford it. We came up with the idea to prepare three different types of vegetable boxes for $20 \mathrm{TL}, 40 \mathrm{TL}$, and $60 \mathrm{TL}$. Consumers bought these boxes and thus prepaid the boxes they would order in the following months. Some also granted money to this project to support this family. This is one example of the solidarity relations we want to build with these last urban farmers in Istanbul.

As noted before, the idea of DÜRTÜK also emerged during the forum and solidarity groups that formed after the Gezi Park protests, which sprouted many of today's collective initiatives in Turkey. A few years ago, a large part of the Yedikule Bostans was razed by the municipality with the claim of transforming it into a public park. Piyalepaşa Bostan was saved in 2015 from being transformed into a car park, yet rumors still persist about it being transformed into a hobby garden for the recently gentrified surrounding neighborhoods. Thus, it becomes even harder for the farmers in these bostans who have cultivated these lands for generations to produce under the precarious conditions of insecure land tenure, while already getting unfair prices in the market. Unfortunately, DÜRTÜK also has irregular operations, opening and closing because of a lack of active volunteers to take responsibility of the weekly operations. The collective seems to have stopped its operations in September 2018, after losing the collaboration of their main contact-farmer who had abandoned farming and all his volunteer efforts as the head of the association of farmers in Yedikule due to pressures from various powerful actors, mainly those with construction plans in the bostan area.

Köstebek Collective: This is an interesting example of a collective organization of volunteers that emerged to establish a publishing cooperative and has recently embarked on growing ecological corn from heirloom kernels to finance the publication costs of the books they prepare collectively. Collectively combining their publishing efforts with their agricultural activities, they aim to challenge the constructed binaries between physical labor and intellectual labor through their slogan, "We cultivate corn and harvest books." They express their motivation for agricultural activities by contributing to an alternative economy and for peoples' food sovereignty by implementing collective agro-ecological techniques and knowledge. They started their corn production in an agricultural field in an Abkhazian village in Düzce, which a farmer friend from the network of food communities had made available for their collective use. They grow Abkhazian corn and beans from heirloom kernels and beans using only animal manure and no agricultural chemicals. Their efforts to grow from heirloom corn kernels are quite valuable in the context of the difficulty of finding corn that has not been genetically modified. They sell these products by organizing sales events in solidarity cafes and cooperatives, as well as by joining events organized by food cooperatives and communities. Some cooperatives like Kadıköy Cooperative have established solidary 
relations with Köstebek Collective by selling corn in the cooperative store for a few weeks after the harvest on behalf of the Köstebek Collective for no profit. Thus, the Köstebek Collective had started agriculture with only a little experience, yet they continue their agricultural activities by collectively learning from their experiences as well as from other collective consumer initiatives and farmers with whom they have constant interactions and solidarity. Through this collective agricultural activity and solidary relations, they try to realize their objective of building production and consumption forms that are alternatives to the agro-food relations imposed by the current corporate food regime.

The food communities of Yeryüzü (Earth) Association: These started in 2012 with the emergence of the Küçükyalı food community in Istanbul. Today, food communities are also found in various neighborhoods of Istanbul, such as Kadıköy, Taksim, Kuzguncuk, Kartal, Beykoz, Göztepe, and Bahçeşehir. Their main aim is to provide ecological products to consumers without intermediaries for more affordable prices and to support small-scale ecological producers who use local heirloom seeds without using pesticides, herbicides, or synthetic fertilizers. Their producers vary from producing tomato sauce, lentils, beans, olives, and rice to herbs, vinegar, olive oil, pomegranate sauce, and honey. These foods mostly are products that are suitable for shipping from all over Turkey without spoiling. These communities pursue not monetary gains but their sustainability. Consumers are invited not only to buy products but also to engage in operating these collective platforms through participatory relations and democratic decision-making processes.

In the last eight years, the number of Yeryüzü food communities has not increased astronomically, but the period after the first public workshop organized by the Yeryüzü Association in 2016 did witness an increase in the number of consumer food cooperatives. In this first public workshop of food communities, Yeryüzü food communities, DÜRTÜK, BÜKOOP, and Kadıköy Coop presented their organizations, motivations, and ways for forming food communities. Small groups were formed to discuss the problems producers face, the limits and possibilities food communities have, ecological production, consumption relations, and so on. This made a good start for catalyzing the interactions among food communities and motivating other groups to form such communities. The workshop has been collectively organized by the Yeryüzü food communities and consumer food cooperatives in each of the following two years. This collaborative organization experience started with those in Istanbul in 2017 and has continued with those throughout Turkey with the call of coming together to solve the common problems hand in hand by discussing collectively the next steps to take in this struggle. The 2019 workshop was organized for the first time under the name "Workshop of Food Communities and Cooperatives." The workshop's coorganization process also increased the interactions and bonds between the Yeryüzü 
food communities and the consumer food cooperatives. Also, because these interactions between food communities and cooperatives have increased, many Yeryüzü food communities today are discussing how to transform into consumer food cooperatives in the short-term.

Their organizational models and logistic strategies are similar but not uniform in each Yeryüzü food community. The number of volunteers in each food community varies, but usually does not exceed 10 active volunteers. The number of consumers not actively volunteering who only shop from the community is much higher. Food communities are mostly autonomous in their management and independent from one another. However, some communities are more dependent on the executive board of the Yeryüzü Association than those in Kadıköy and Taksim (i.e., the largest food communities in Istanbul) in terms of getting in touch with new producers and managing collective orders. The lack of entirely autonomous management in each community is a point open for improvement because each community needs to fully manage all their operations, make decisions collectively in their group according to the particular needs and motivations consumers in each locality have, and implement participative democracy more effectively; these are the crucial objectives Yeryüzü food communities have, like many consumer food cooperatives in Istanbul.

In terms of the logistics for food orders, food communities circulate monthly an excel sheet containing the information on producers and products, mostly coming together monthly on the predetermined distribution day to receive their collective orders. Each producer cargoes all orders together for these network members to reduce shipping costs and to minimize time and effort. Only the small-scale producers who practice ecological/organic farming are included on the list. Producers can apply for inclusion on the list by contacting the relevant community. The consumers decide collectively whether the products and production conditions satisfy their collectively defined criteria. Food communities sell a greater number of small-scale family farm products than food cooperatives because food communities, unlike cooperatives, do not sell these products in a store, where only products are sold that conform to certain legal requirements (i.e., the etiquette of product compatibility with the Turkish Food Codex).

Forming a food community is easier compared to establishing a formal consumer food cooperative with a cooperative store. This lack of legal procedures or extra efforts of running a physical store that food communities have is a considerable practical advantage for consumers to come together in their neighborhoods. However, it also becomes an obstacle for food communities in terms of their public visibility regardless of all efforts. This is because the local cooperative stores in neighborhoods are publicly visible collective spaces that invite more consumers to become active agents in the collective work in addition to being consumers by having face-to-face interactions 
with a larger range of consumers and informing them about their collective organization. A similar problem where active volunteers are lacking is also seen in consumer food cooperative organizations, yet not to the same extent as food communities. Consumer cooperatives always have some volunteers with similar ideas joining and leaving, but the number of active volunteers is always sufficient for being able to maintain these cooperative efforts, as opposed to what is experienced in most food communities.

Now, I would like to move on to a discussion of the transformative examples that consumers and producers in this network of ecological food initiatives have given so as to indicate their hope of changing current agro-food relations by expanding such initiatives. These consumers and producers also explain in detail why they perceive these initiatives' collective practices as something political and how they relate their practices to the food sovereignty movement in the context of Turkey. I believe the following section on the framework of food sovereignty and commonality of food politics will help in understanding better why I prefer focusing on and discussing the collective, participative, consumer-led ecological initiatives rather than other so-called 'alternative' food channels.

\section{Discussion and Further Analysis of the Fieldwork}

\section{Building Hope in the Network of Collective Ecological Initiatives in the Context of Turkey's Oppressive Agro-Food and Pessimist Politics}

Collective organization of the division of labor (food, cleaning, security, health services, etc.) in the Gezi Park protest in 2013 as well as the collective discussions, democratic decision-making, and participatory structure solidarity groups attempted to realize after the Gezi Park protests were transformed later in the eyes of many citizens into the opportunity for self-organization around common concerns in a context marked by the increased oppression of the state to block the voices opposing them from mobilizing in the streets. The excitement and synergy of the Gezi experience has continued in neighborhood forums and solidarity groups with multiple voices, democratic participation, and division of labor. As Akçay and Kocagöz (2018, p. 36) explained, the forums and neighborhood solidarity groups have created 1) an environment where everyone can speak up and hear each other's opinions about everything, even those who have never met before, 2) a place where citizens can address a large range of topics in the forum area and then discuss what can be done collectively to solve these problems at the neighborhood scale, and as a result 3) the possibility of establishing concrete participative politics at the local level by taking responsibility in their locality. The idea for many consumer food cooperatives emerged in the post-Gezi period, mostly starting with a group of neighbors who met in solidarity groups that had continued for a while. Others were also inspired by the recent rise of 
citizens self-organizing their communities and cooperatives around food because consumers' food anxieties had intensified as the food industry and conventional farming increasingly became more dominant in the context of agro-food.

Before, we couldn't express this as being political. We were saying "I am an ecologist. We do not give a political message here; we only defend life." After Gezi we have now gone far beyond that naive position. I think that many ecologists and collectives also felt this breaking point. Now we admit clearly that what we are doing in our local organizations in villages or cities is certainly being political. Imagine a boat where some people row against the tide individually. To strengthen the resistance and build solidarity, some people stand together as rocks next to each other, here and there in the river so that they can direct the water to their aim (what we all aim at), instead of being dragged along the flow. (An activist from the Yrrca female collective)

You know, we were saying "another way is possible" in Gezi. We are now searching for and discussing these very ways, offering one of the many techniques of building this pathway and inviting people to join us on this road. We want to touch the lives of producers and transform the production and consumption relations in this system. We know that we will make greater changes through our ideals as those like us increase in number and organize. Yet, we have just started to do so. (A volunteer from Beşiktaş Cooperative)

Akçay and Kocagöz (2018) asked a crucial question: "Can we reconsider an alternative political topography departing from our experiences in the grey zone that exists at the intersection of the current and the emerging possibilities?" (p. 35). I consider this question very important because, despite having dark days today, these recent organizations and perspectives have emerged as new possibilities after the Gezi Park protests and try to offer some alternatives from within a grey zone. Thus, analyzing the concrete efforts as well as the significant motivations and hopes these initiatives try to build through alternative participatory politics in food and agriculture is essential, even if they have yet to mature.

The activists in these initiatives conceptualize food as a complement of processes from production to consumption that comprise many actors and power relations and have several political, economic, and social dimensions. At first sight, these initiatives do not seem like a resistance for reclaiming our commons. However, these volunteers consider food as our commons and thus try to expand and support local peasant knowledge and agro-ecological techniques, as well as to protect heirloom seeds, agricultural lands, and rivers from the capitalist invasion. By considering food as a political matter and our commons, they thus pay utmost attention to which seeds are used in the production (local and heirloom seeds; not the hybrid seeds from corporations) and what kind of labor relations are seen in the production processes of their foods (non-exploitation of labor as opposed to the logic of capitalist accumulation). They also organize panels and workshops to create public awareness. For instance, they get together to discuss recent regulations concerning local seeds, where farmers are obliged to patent their seeds at considerable cost to be able to market them, thus indeed paving 
the way for corporations to own the property rights of seeds which has been our commons for centuries.

The volunteers from these initiatives, especially those with a more participatory model, often highlight that these civic democratic platforms try to offer citizens efficient tools and models to act for themselves around a common and daily matter like food and to take back the public space the state tries to seize by using democratic and participative relations:

This is a place where people know how to listen to each other and value others' words. Here we know that listening and a participative discussion are the prerequisites of doing collective work. We discuss everything here, from the properties of the products we will buy, which producers to work with, how to better organize our division of labor... One of the main reasons why I am here is that this platform provides a collective organizational model for taking action on the matters I am concerned with in my daily life and for putting these concerns in common with others for having our voice in the politics of food. (A volunteer from the Yeryüzü Association)

We are indeed one of the actors that can be defined in new social movements through our selforganization where the actors have no defined hierarchy in this collective effort and the responsibilities between consumers and producers are mutual. This organization thus offers an up-to-date model for reorganizing rural-urban relations at a new conjuncture marked by the dissolution of small farming. (A volunteer from Kadıköy Cooperative)

These collective ecological initiatives also give considerable value to mutual initiatives and to dialogue between them and producers to transform producer-consumer relations as well as production conditions and forms. Kadıköy Cooperative volunteers in particular have given several examples of the transformation initiated by the collaboration of producers and the cooperative, indicating the transformative power of such relations and practices.

You know, Devrek Female Cooperative contacted us to sell traditional noodles (erişte). But they were using industrial flour from hybrid wheat seeds. We requested them to produce ecological noodles and tarhana for us from heirloom wheat seeds. They said they'd like to do so but didn't know any ecological wheat producers. We offered them to contact directly one of our wheat producers, and thus they started selling us ecological noodles and tarhana from heirloom seeds. The final product was more expensive than the previous one, yet much cheaper than its certified organic counterparts, and the consumers in Kadıköy really liked these products. So we had transformed a producer cooperative's form of production through direct communication by raising awareness about the value of heirloom seeds and the dangers of industrial ones. Şişli Coop Initiative included these products in their food boxes at that time, so we also had an effect upon another consumer initiative. The next step is much more valuable. These women in the cooperative told us that they don't want to 'poison' consumers anymore, that they want to cultivate their wheat ecologically from heirloom seeds. A group of architects, some of whom are from Beşiktaş and Kadıköy Coops, offered to design a stone mill project for them. We built this transformation process all together in direct communication and solidarity based on taking mutual initiatives. The women have now started to produce ecological products made from their own wheat from heirloom seeds. 
When we directly contact the hazelnut producer and say "We will buy $300 \mathrm{~kg}$ of ecological hazelnut for a fair price you offer," we exclude all other intermediary actors from the system. Based on direct communication, we then make sure that producer uses neither chemicals nor synthetic fertilizers and doesn't exploit labor, including migrants. In this process, we witness the dynamics and production conditions of the family farm as well as the meaning of the fair compensation he gets from this production. We did this by mutually taking initiatives with the producer and paying the fair price determined by Find1k-Sen. This is how we can change the production, consumption, and distribution relations of food. Local newspapers published this news as "The Fairest hazelnut is in Kadiköy Coop." We ordered these hazelnuts the following year together with Koşuyolu Coop. This year, Fındık-Sen says, "Go away corporations, long live cooperatives and co-operations." They didn't have this slogan last year.

Producers in the network of these collective ecological initiatives also believe in the potential such platforms have and consider the collaboration of producers and consumers as hopeful developments.

I feel so lucky to be able to talk with you (Kadıköy Cooperative volunteer) today. This direct communication is so valuable. It is empowering to see that consumers get organized because they have start to realize that some things have been going badly in this system. More people will realize this and these initiatives will grow. I am hopeful, otherwise, I couldn't go on. We don't have capital; we are very small, but small ecological farmers exist... and we need your support. (A producer in Manyas)

I do believe that lots of things will change once more people become part of such initiatives and more consumers buy from there. First of all, ecological production will increase. People might go back to their lands and migration to cities might decrease. This is because people in villages can get fair prices, because producing ecologically is valuable for many urban consumers (...) The non-existence of intermediaries is also a crucial tool for the rural development model in Turkey. I believe that the only model that can save Turkey from these recent crises is the cooperative model. (A producer cooperative member in Seferihisar)

Both the volunteer consumers and producers are indeed aware of the restricted scope of their network and currently limited impact, despite their increasing numbers. The activists/volunteers in these initiatives also consider themselves as crucial actors with the potential to create meaningful alternatives in the cracks of the capitalist system. Thus, the practices of citizens' collective democratic self-organization give hope to many in the context of the economic and political pressure in Turkey.

We do not seem yet as powerful opponents in the eyes of the state. However, we do give the signals of creating small cracks in the capitalist system today. We can do this not alone but only with an increasing network of democratic structures to build tomorrow. There is no one to rescue us, no big rebellions... When we increase our objection in numbers, this objection to the existing system will naturally carry an anti-capitalist character to create transformation (...) Because what we are doing today is already an alternative to the capitalist relations in the current agro-food system, despite currently having a small scope. (A volunteer from Kadıköy Cooperative) 
Recent years have seen a growing and incrementally visible wave of cooperative organizations and consumer communities, as well as a growing public discourse about cooperatives. In this recent context, vigilance on the matter of being a 'meaningful' alternative with transformational visions and on the risk of conventionalizing those with primarily transformational ambitions has become important. Therefore, we always need to analyze the questions asked in this research: What kind of ecological, economic, and social relations do these cooperatives aim to change and how? Do they have a participative and democratic organization model for expanding the scope of cooperation for such ideals? Or do they simply become another option in the market, acting with conventional production and consumption relations? In this regard, I believe that very closely researching the trajectory of these cooperatives/communities and their practices in the following years will be crucial, just as participating in these platforms to become agents who act for this hopeful transformation for an alternative understanding of citizenship and an alternative agro-food system will be essential.

\section{Peer-review: Externally peer-reviewed.}

Conflict of Interest: The author declares no potential conflicts of interest with respect to the research, authorship, and/or publication of this article.

Grant Support: The author received no financial support for the research, authorship, and/or publication of this article.

\section{References}

Akçay, E., \& Kocagöz, U. (2018). Bir siyaset rasyonalitesi olarak müşterekleştirme. Felsefelogos, 68, 31-41. Aydın, Z. (2010). Neo-liberal transformation of Turkish agriculture. Journal of Agrarian Change, $10(2), 149-187$.

Aysu, A. (2015). Gida krizi: Tarım, ekoloji ve egemenlik. Metis Yayınları.

Aysu, A. (2019). Kooperatifler. Yeni İnsan Yayınevi.

Bourdieu, P. (1984). Distinction: A social critique of the judgement of taste [La Distinction] (R. Nice, Trans.). Routledge.

Buck, D., Getz, C., \& Guthman, J. (1997). From farm to table: The organic vegetable commodity chain of Northern California. Sociologia Ruralis, 37(1), 3-20.

Buğday Association (December 2019). Ecological Farmers' Markets. http://ekolojikpazarlar.org/

Buttel, F. H. (1997). Some observations on agro-food change and the future of agricultural sustainability movements. In D. Goodman \& M. Watts (Eds.), Globalising food: Agrarian questions and global restructuring (pp. 344-365). Routledge.

Ekoharita. (December 2019). Ecological map. https://www.ekoharita.org/ekoloji-haritasi/

European Coordination Via Campesina (2018). A guide to food sovereignty. https://viacampesina. org/en/wp-content/uploads/sites/2/2018/02/Food-Sovereignty-A-guide-Low-Res-Vresion.pdf

European Central Bank (2019, December 10). Turkish Lira to Euro exchange rate. http://sdw.ecb.europa. eu/quickview do;jsessionid=782FBE71E90C841856120CF8468E08DE?SERIES_KEY=120. EXR.D.TRY.EUR.SP00.A

Food and Agriculture Organization (1999). Recommended international code of practice: General principles of food hygiene. http://www.fao.org/3/y1579e/y1579e02.htm 
Goodman, D., \& Goodman, M. (2007). Localism, livelihoods and the 'post-organic': changing perspectives on alternative food networks in the United States. In D. Maye, L. Holloway, \& M. Kneafsey (Eds.) Alternative food geographies (pp. 23-39). Elsevier.

Jones, O., Kirwan, J. Dunn, H., Hopkins, A., Whittington, F., Buller, H., \& Morris, C. (2010). On the alternativeness of alternative food networks: sustainability and the co-production of social and ecological wealth. In D. Fuller, A. Jonas, \& R. Lee (Eds.), Interrogating alterity (pp. 95-110). Routledge.

Kadirbeyoğlu, Z. (2016). Alternative food initiatives for environmental justice: Marginal or transformative? Paper presented at the IRSA: XIV World Congress of Rural Sociology. https:// orgprints.org/30010/25/IRSA_World\%20Congress\%20Presentations_Jan17.pdf

Kadirbeyoğlu, Z., \& Konya, N. (2017). Alternative food initiatives in Turkey. In F. Adaman, B. Akbulut, \& M. Arsel (Eds.) Neoliberal Turkey and its discontents: Economic policy and the environment under Erdogan (pp. 39-41). Taurus.

Karakaya, E. (2016). Agro food system transitions? Exploring alternative agro food initiatives in İzmir, Turkey (Unpublished doctoral dissertation). https:/openaccess.iyte.edu.tr/ handle $/ 11147 / 4874$ ?locale-attribute $=$ tr

Keyder, Ç., \& Yenal, Z. (2013). Bildiğimiz tarımın sonu: Küresel iktidar ve köylülük. İletişim Yayınları.

Kocagöz, U., \& Doğançayır, C. M. (2017, April 24). Operationalizing food sovereignty: A critical approach from an ongoing experiment in Turkey. Paper presented at the International Colloquium on the Future of Food and Challenges for Agriculture in the 21st Century. Vitoria-Gasteiz, Spain. https://www.academia.edu/37488790/Operationalizing_Food_Sovereignty_a_critical_approach_ from_an_ongoing_experiment_in_Turkey

Marx, K. (2015). Kapital (Cilt 1, M. Selik, çev.). Yordam.

McMichael, P. (2009). A food regime geneology. Journal of Peasant Studies, 36(1), 139-169.

McMichael, P. (2013). Food regimes and agrarian questions. Fernwood Publishing.

McMichael, P. (2016). Commentary: Food regime for thought. The Journal of Peasant Studies, 43(3), 648-670.

Ministry of Agriculture and Forestry (2018). Statistics on organic agriculture 2002-2018. https:// www.tarimorman.gov.tr/Konular/Bitkisel-Uretim/Organik-Tarim/Istatistikler

Ministry of Food, Agriculture, and Livestock (2018). Budget presentation, November 2017. https:// www.tarimorman.gov.tr/Belgeler/ButceSunumlari/ButceSunumu_2018.pdf

Öngel, F. S., \& Yıldırım, U. D. (Eds.) (2019). Krize karşı kooperatifler: deneyimler, tartışmalar, alternatifler. Notabene Yayıları.

Research Institute of Organic Culture \& the International Federation of Organic Agriculture Movements. (2016). Organic in Europe: Statistics and emerging trends 2016.

Research Institute of Organic Culture \& the International Federation of Organic Agriculture Movements. (2019). The world of organic agriculture: Statistics and emerging trends 2019. https://ciaorganico.net/documypublic/486_2020-organic-world-2019.pdf

Soysal A., I., \& Küçük, B. (2019). In-between anxiety and hope: Trusting an alternative among 'alternatives' in the (post) organic food market in Turkey. The International Journal of Sociology of Agriculture and Food, 25(2), 173-190.

Şık, B. (2017, March 28). Glifosat kalıntısı GDO’lu ekmek kadar önemli bir halk sağglığ sorunu. https://bianet.org/bianet/tarim/184902-glifosat-kalintisi-gdo-lu-ekmek-kadar-onemli-bir-halksagligi-sorunu 